\title{
BUDAYA DALAM PENERJEMAHAN BAHASA
}

\section{Hatmiati, Husin}

STKIP PGRI Banjarmasin, STIQ Amuntai, Kalimantan Selatan Email: hatmiati_mpd@yahoo.com,husin@stiq-amuntai.ac.id

\begin{abstract}
Abstrak
Artikel ini secara ringkas-konseptual membahas tentang buku "Penerjemahan Arab-Indonesia Antara Bahasa dan Budaya" yang ditulis oleh H. Hasan, MA, Hum dan sekarang menjabat sebagai ketua program studi Pendidikan Bahasa Arab di Sekolah Tinggi Ilmu Alquran (STIQ) Amuntai. Peneliti mencoba membedah isi dari buku "Penerjemahan Arab-Indonesia (Antara Bahasa dan Budaya) dengan menggunakan jenis penelitian library research dan agar data yang diperoleh nantinya dapat dijadikan sebagai bahasan yang akurat, maka peneliti dalam menganalisis data yang dimaksud dengan menggunakan metode pengolahan data dan analisis data yang bersifat deskriptif dengan cara berfikir deduktif komparatif juga menggunakan content analysis. Hasil penelitian menunjukkan bahwa bahasa tidak hanya berfungsi sebagai alat komunikasi, tetapi lebih dari itu bahasa juga berfungsi sebagai penyebar ilmu pengetahuan, seni, dan teknologi. Selain itu, dalam proses penerjemahan, penguasaan bahasa sumber saja tidak mencukupi, seorang penerjemah juga harus mengetahui latar belakang sosial budaya, tujuan, dan sasaran pembaca dari teks tulisan tersebut. Sejalan dengan hal tersebut, dijelaskan pula bagaimana fungsi bahasa, budaya, penerjemahan, dan hubungan bahasa dan budaya dalam proses penerjemahan.
\end{abstract}

Kata Kunci: bahasa, budaya, dan penerjemahan

\section{PENDAHULUAN}

Satu di antara anugerah terbesar yang diberikan Allah swt kepada manusia adalah kemampuan berbahasa. Bahasa mampu mewadahi segala bentuk ekspresi manusia dalam bentuk tulisan dan lisan. Sehingga, sukar dibayangkan manusia hidup tanpa bahasa. Bahasa membuat seseorang mengenal nilai-nilai yang mempengaruhi dimensi sosial budayanya. Bahasa juga dapat menjadi cermin kehidupan manusia karena melalui bahasa orang bisa dengan mudah menuangkan idenya, pengalamannya, perasaannya, dan emosinya. Bahkan lewat bahasa seseorang mampu berkreativitas, mengemukakan segala yang ingin dia katakan tanpa harus menghindar dan tanpa harus kehilangan jiwa. 
Bahasa menyediakan lahan basah tempat segala kreativitas bisa tergali dan muncul mengecambah hingga tumbuh subur mengabarkan segala yang pantas terkabar dan tersampaikan. Oleh karena itu, ada satu ungkapan yang menyatakan bahwa bahasa menunjukkan identitas seseorang, ada juga bahasa menunjukkan bangsa. Begitu pentingnya peranan bahasa dalam kehidupan bermasyarakat, maka banyak penelitian mengenai bahasa ini dilakukan, baik dari segi sistem bahasa maupun keterkaitan bahasa dengan bidang-bidang ilmu yang lain, seperti budaya, psikologi, maupun filsafat. Sependapat dengan Kaimuddin, Husin juga menjelaskan bahwa di dalam tumbuh kembangnya masyarakat terdapat unsur nilai-nilai budaya,bahasa, serta ragam perilaku sosial yang tidak hanya menjadi tanggungjawab masyarakat melainkan juga tanggung jawab lembaga pendidikan dimana lembaga pendidikan merupakan wadah yang terorganisir dan efektif untuk melanggengkan unsur-unsur tersebut. ${ }^{1}$

Ada banyak teori tentang hubungan antara bahasa dan budaya. Diantaranya mengatakan bahwa bahasa itu merupakan bagian dari budaya sehingga hubungannya bersifat subordinat tetapi ada juga yang mengatakan bahwa bahasa dan budaya merupakan dua hal yang berbeda namun mempunyai hubungan yang erat sehingga hubungannya bersifat koordinatif. Ada pula yang mengatakan bahwa budaya dipengaruhi oleh bahasa dan ada juga yang yang menyatakan sebaliknya. ${ }^{2}$ Sebab itulah Abdullah Zainur Rauf dengan mengutip pendapat Enok Maryani menyatakan bahwa antara bahasa dan budaya terdapat keterkaitan yang sangat erat. Bahasa adalah salah satu alat (media) yang sangat penting dalam mempelajari warisan kebudayaan. ${ }^{3}$ Zamzani juga menegaskan bahwa diskusi tentang hubungan bahasa dan kebudayaan perlu mendapatkan porsi tersendiri dalam meletakkan posisi bahasa dalam kaitannya dengan pendidikan berbasis keragaman budaya. ${ }^{4}$

${ }^{1}$ Husin, "Perkembangan dan Perubahan Kurikulum Pendidikan Islam di Indonesia", Addabana 1, no. 2 (2018): h. 77. Lihat juga Kaimuddin, "Pengembangan Kurikulum Pendidikan Tinggi”, Jurnal Al-Ta'dib 8, no. 1 (2015): h. 15.

${ }^{2}$ Aunul Hakim, "Bahasa dan Budaya" Turats Vol 6, no. 1 (2014), h. 2.

22.

${ }^{3}$ Abdullah Zainur Rauf, “Dialektika Bahasa Dan Budaya,” Al-Qudwah, (2006), h.

${ }^{4}$ Zamzani, "Eksistensi Bahasa Indonesia Dalam Pendidikan Berbasis Keragaman Budaya”, Dialektika 1, no. 2 (2014): h. 228. 
Setiap bahasa memiliki ciri khas yang berbeda dari bahasa lainnya. Kekhasan bahasa ini dapat terjadi karena dipengaruhi oleh budaya darimana bahasa tersebut berasal. Perbedaan bahasa ini akan menjadi persoalan serius ketika seseorang akan berkomunikasi dengan orang lain yang menggunakan bahasa berbeda. Dalam kondisi demikian, maka diperlukan seorang penerjemah untuk mengalihbahasakan tuturan maupun teks tertulis ke dalam bahasa sasaran. Oleh karena itu, seorang penerjemah harus memiliki kemampuan untuk menguasai bahasa sumber dan menerjemahkan ke dalam bahasa sasaran. Proses menerjemahkan sebuah bahasa ini bukan hanya sekedar mengalihbahasakan sebuah bahasa sumber tetapi juga berperan dalam penerjemahan sebuah budaya yang berasal dari bahasa sumber.

\section{METODOLOGI PENELITIAN}

Untuk mengumpulkan data, peneliti menggunakan penelitian kepustakaan (library research) yaitu dengan cara menelaah referensi atau literatur yang terkait dengan bahasa dan budaya, baik yang berbahasa asing maupun yang berbahasa Indonesia.

Karena penelitian ini ingin mengungkapkan ide dan gagasan penulis buku Penerjemahan Arab-Indonesia (Antara Bahasa dan Budaya) sekaligus menganalisis serta memberikan sedikit kontribusi pemikiran/sudut pandang yang bisa melengkapi ide penulisnya, maka bahan primer dari penelitian ini adalah buku Penerjemahan ArabIndonesia (Antara Bahasa dan Budaya) itu sendiri. Sedangkan bahan sekunder diambil dari hasil penelitian/artikel/jurnal lain yang bisa memberikan sudut pandang yang bebas dan objektif.

Agar data yang diperoleh nantinya dapat dijadikan sebagai bahasan yang akurat, maka peneliti dalam menganalisis data yang dimaksud dengan menggunakan metode pengolahan data dan analisis data yang bersifat deskriptif dengan cara berfikir deduktif komparatif juga menggunakan content analysis. 


\section{PEMBAHASAN}

\section{Fungsi Bahasa dan Masyarakat Bahasa}

\section{Bahasa}

Bahasa secara ringkas dapat diartikan sebagai sarana untuk menjelaskan atau menyampaikan suatu maksud. Secara umum, bahasa merupakan sarana untuk berinteraksi atau berkomunikasi untuk menyampaikan pikiran, gagasan, konsep atau perasaan kepada lawan tutur. Secara sosiolinguistik, bahasa diartikan sebagai sebuah sistem lambang, berupa bunyi, bersifat arbitrer, produktif, dinamis, beragam dan manusiawi. Dengan demikian, setiap individu dalam masyarakat dipastikan memiliki dan menggunakan alat komunikasi berupa bahasa yang memiliki sistem dan pemahaman yang sama, sehingga bahasa tersebut dapat digunakan secara maksimal. Tidak ada masyarakat tanpa bahasa, dan tidak ada pula bahasa tanpa masyarakat.

Tetapi, pada kenyataannya tidak semua bahasa yang digunakan antara penutur dan mitra tutur menimbulkan pemahaman yang sama. Hal ini dapat terjadi karena penutur tidak mengungkapkan apa yang ingin disampaikan dengan sesuai dengan bahasa yang ingin dikatakannya sehingga mengaburkan makna yang ingin diungkapkan. Hal ini sejalan dengan pendapat Ibrahim yang menyatakan bahwa apabila penutur bahasa selalu mengatakan apa yang mereka maksudkan, maka tidak akan terdapat banyak masalah dalam teori tindak tutur maupun dalam analisis wacana. Tetapi tentu saja penutur tidak selalu menyatakan maksud seperti apa yang mereka katakan. ${ }^{5}$

Hal tersebut di atas dapat dibaca pada contoh berikut. Dua orang ibu Banjar berjalan bersama, sepulang yasinan/arisan. Seorang ibu yang kebetulan letak rumahnya lebih dekat dan tiba lebih dahulu, berkata "singgahkah?". Dalam kondisi seperti ini, ibu kedua menjawab, "Inggih, kaina haja". Apa yang hendak diperlihatkan di sini adalah "singgahkah?" sebenarnya tidak menyilakan singgah seperti yang diperlihatkan oleh sistem gramatikanya, tetapi sesuai dengan pengguna bahasa tersebut, kalimat itu hanya berarti basa-basi pergaulan saja. Jika suatu kelompok orang atau suatu masyarakat mempunyai verbal repertoire yang relatif sama serta mereka mempunyai penilaian yang sama terhadap normah. 105.

${ }^{5}$ Abdul Syukur Ibrahim, Kajian Tindak Tutur (Surabaya: Usaha Nasional, 1993), 
norma pemakaian bahasa yang digunakan di dalam masyarakat itu, maka kelompok orang tersebut adalah sebuah masyarakat bahasa/tutur (Speech Commnunity). Chaer \& Agustina berpendapat verbal repertoire adalah semua bahasa beserta ragam-ragamnya yang dimiliki atau dikuasai seorang penutur. ${ }^{6}$

Fishman mengemukakan bahwa masyarakat tutur adalah suatu masyarakat yang anggota-anggotanya mengenal minimal satu variasi bahasa beserta norma-norma yang sesuai dengan penggunaannya. Kata masyarakat bersifat relatif, dapat menyangkut masyarakat luas maupun sekelompok kecil orang. Misalnya: masyarakat Kalimantan Selatan, masyarakat pendidikan. ${ }^{7}$ Sejalan dengan hal tersebut Ibrahim mendefinisikan tindak tutur memiliki fungsi psikologis dan sosial di luar wacana yang sedang terjadi. ${ }^{8}$ Tindak tutur yang dilakukan seseorang selalu memiliki makna sesuai dengan keinginan si penutur. Akan tetapi, makna tersebut kadang-kadang bertentangan dengan apa yang dipahami oleh mitra tutur. Hal ini dapat terjadi dalam setiap aspek kehidupan. Implikasi dari pemahaman yang berbeda akan membuat pokok persoalan yang disampaikan tidak akan dapat memenuhi harapan penutur dan mitra tutur. Artinya, makna yang tersurat pada sebuah tuturan, tidak selalu sama dengan makna yang tersirat.

Pada dasarnya, masyarakat bahasa itu terbentuk karena adanya saling pengertian (mutual intelligibility), terutama karena adanya kebersamaan dalam kode-kode linguistik, selain memilik persamaan nilai terhadap norma-norma pemakaian bahasa yang ada dalam masyarakat tersebut. Alwasilah mengungkapkan bahwa masyarakat itu terbentuk karena adanya saling pengertian, terutama karena adanya kebersamaan dalam kode-kode linguistik yaitu sistem bunyi, sintaksis dan semantik. Dengan begitu maka sebenarnya dalam pengertian masyarakat sudah terkandung makna interaksi melalui komunikasi yaitu bahasa. ${ }^{9}$ Variasi bahasa yang muncul saat ini kebanyakan disebabkan oleh adanya kegiatan interaksi sosial masyarakat atau kelompok yang sangat beragam dan dikarenakan oleh para penuturnya yang tidak

${ }^{6}$ Abdul Chaer dan Leoni Agustina, Sosiolinguistik: Perkenalan Awal (Jakarta: Rineka Cipta, 2004), h. 35.

${ }^{7}$ Joshua A. Fishman, The Sosiology of Language (Massachussets: Newbury House Publisher, 1976), h. 28.

${ }^{8}$ Abdul Syukur Ibrahim, Kajian Tindak Tutur ..., h. 109.

${ }^{9}$ Adeng Chaedar Alwasilah, Sosiologi Bahasa (Bandung: Angkasa, 1986), h. 43 
homogen. Pulau Jawa dengan segala pesonanya yang ada menarik banyak suku atau bahwa bangsa lain untuk tinggal dan menetap, mencari pekerjaan dan bermasyarakat dengan lingkungan sekitar. Dalam mengkaji variasi bahasa terdapat dua pandangan yang dapat kita jadikan sebagai tumpuan. Pandangan pertama memandang bahwa variasi bahasa merupakan akibat dari banyaknya keberagaman dan fungsi bahasa. Kedua, variasi bahasa dipandang telah muncul dengan sendirinya memenuhi fungsinya sebagai interaksi dalam bahasa masyarakat yang beraneka ragam. Pendapat ini selayaknya dapat diterima atau tidak.

Dalam teks tertulis, seorang pembaca akan memahami apa yang disampaikan oleh penulis apabila bahasa yang digunakan sama dengan bahasa yang digunakan oleh pembaca. Oleh karena itu, apabila sebuah teks tertulis tidak dipahami oleh pembaca karena berbeda bahasa yang digunakan, maka diperlukan penerjemah yang memahami bahasa sumber dan memahami bahasa sasaran. Penerjemah berada dalam dua sisi, yaitu dari sisi bahasa dan dari sisi budaya sebuah masyarakat agar dia mampu menghasilkan sebuah karya terjemah yang mudah dipahami oleh pembaca. Hal ini sejalan dengan pendapat Larson yang menjelaskan bahwa terjemahan yang baik memiliki tiga kriteria, yakni ketepatan, kejelasan, dan kewajaran. Ketepatan adalah karya terjemahan harus menyampaikan pesan sesuai dengan yang dimaksud oleh penulis dalam bahasa sumber, kejelasan adalah karya terjemahan mudah dipahami oleh pemabaca sasaran, dan kewajaran berhubungan dengan gaya dan bentuk gramatikal yang harus wajar, sesuai dengan kaidah bahasa sasaran. ${ }^{10}$

\section{Budaya}

Budaya ada seiring dengan adanya peradaban manusia. Hatmiati berpendapat bahwa budaya merupakan hasil cipta manusia yang ada seiring dengan manusia itu sendiri. ${ }^{11}$ Budaya mengkonstruksikan setiap keadaan yang mencerminkan nilai-nilai kehidupan yang diyakini oleh

${ }^{10}$ Mildred L. Larsaon, Penerjemahan Berdasarkan Makna: Pedoman Untuk Pemadanan Antarbahasa (diterjemahkan oleh Kencanawati Taniran dari Meaning Based Translation, A Guide to Crosslanguage Equivalence) (Jakarta: Penerbit ARCAN, 1989), h. 53.

11Hatmiati, Pemali dalam Tradisi Lisan Masyarakat Banjar (disertasi tidak diterbitkan: 2016), h. 50 . 
masyarakat. Liliweri berpendapat bahwa setiap masyarakat memiliki kebudayaan yang terbentuk oleh sistem kepercayaan, sistem religi yang sebagian besar dikenal sebagai agama. ${ }^{12}$ Douglas juga menjelaskan bahwa budaya merupakan semangat moral dan intelektual suatu organisasi dalam bentuk tertentu. ${ }^{13}$ Budaya adalah sistem sosial yang dinamis interaktif dan berkembang. Pada setiap titik waktu budaya suatu masyarakat terlibat dalam produksi bersama makna. Spradley dan McCurdy mendefinisikan budaya sebagai pengetahuan masyarakat yang diperoleh digunakan untuk menafsirkan pengalaman dan menghasilkan perilaku. 14 Hal tersebut dapat dilihat dari bagaimana orang menggunakan budaya mereka untuk menafsirkan pengalaman dan melakukan hal-hal tertentu dalam kehidupan mereka sehari-hari. Jenks berpendapat bahwa kebudayaan dipahami sebagai seluruh cara hidup yang dimiliki oleh sekelompok masyarakat. ${ }^{15}$

Honigmann dalam Koentjaraningrat mengemukakan tiga gejala kebudayaan, yaitu (1) ideas, (2) activities, dan (3) artifacts. Tiga gejala kebudayaan tersebut sebagai berikut.

1. Wujud kebudayaan sebagai suatu kompleks dari ide, gagasan, nilai, norma, peraturan, dan sebagainya.

2. Wujud kebudayaan sebagai suatu kompleks aktivitas serta tindakan berpola dari manusia dalam masyarakat.

3. Wujud kebudayaan sebagai benda-benda hasil karya manusia. ${ }^{16}$

Setiap budaya yang ada dalam masyarakat memiliki nilai-nilai yang menjadi pedoman dalam kehidupan. Koentjaraningrat, berpendapat bahwa walaupun nilai budaya berfungsi sebagai pedoman hidup manusia dalam masyarakat, tetapi sebagai konsep, suatu nilai budaya itu bersifat sangat umum, mempunyai ruang lingkup yang sangat luas, dan biasanya sulit diterangkan secara rasional dan nyata. Namun,

108.

${ }^{12}$ Alo Liliweri, Pengantar Studi Kebudayaan (Bandung: Nusa Media, 2014), h.

${ }^{13}$ Mary Douglas, Traditional Culture-Let's Hear No More About It dalam Culture and Public Action Edited byVijayendra Raoand Michael Walton. (Stanford, California: Stanford University Press, 2004), h. 104.

${ }^{14}$ James Spradley, David W. McCurdy, Conformity and Conflict Reading in Cultural Anthropology (United States of Amerika: Pearson Education, Inc., 2012), h. 9. 11.

${ }^{15}$ Chris Jenks, Culture Studi Kebudayaan (Yogyakarta: Pustaka Pelajar, 2013), h. h. 150 .

${ }^{16}$ Koentjaraningrat, Pengantar Ilmu Antropologi (Jakarta: Rineka Cipta, 2009), 
justru karena sifatnya yang umum, luas, dan tidak konkret itu, maka nilai-nilai budaya dalam suatu kebudayaan berada dalam daerah emosional dari alam jiwa para individu yang menjadi warga dan kebudayaan bersangkutan. Selain itu, para individu tersebut sejak kecil telah diresapi dengan nilai budaya yang hidup dalam masyarakatnya sehingga konsep-konsep itu sejak lama telah berakar dalam alam jiwa mereka. ${ }^{17}$

Koentjaraningrat berpendapat bahwa ada tujuh unsur dalam kebudayaan yang dite-mukan di dunia, yaitu:

1. Bahasa

2. Sistem pengetahuan

3. Organisasi sosial

4. Sistem peralatan hidup dan teknologi

5. Sistem mata pencarian hidup

6. Sistem religi

7. Kesenian. ${ }^{18}$

Dalam bentuk yang lebih rinci Liliweri yang menyatakan bahwa nilai-nilai budaya itu dibentuk dari beberapa sumber, antara lain (1) adaptasi dengan lingkungan, (2) faktor-faktor sejarah, (3) evolusi sosial dan ekonomi, (4) kontak dengan kelompok budaya lain, (5) pesan-pesan dalam keluarga kepada anak-anak, (6) cerita rakyat tentang kebudayaan, (7) tekanan masyarakat melalui pemberian hukuman dan ganjaran, (8) pendidikan agama, (9) pendidikan formal, dan (10) kelompok inti.19 Bertolak dari pendapat para ahli tersebut maka setiap karya tulis akan membawa budaya di dalamnya yang hanya dipahami oleh orang yang mengerti budaya bahasa sumber yang melatarbelakangi karya tulis tersebut.

\section{Penerjemahan}

Penerjemahan dalam Kamus Besar Bahasa Indonesia diartikan sebagai proses, cara, perbuatan menerjemahkan; pengalihbahasaan. ${ }^{20}$ Sejalan dengan hal tersebut, Nida dan Taber juga menjelaskan penerjemahan merupakan pengungkapan kembali pesan dalam bahasa sumber ke dalam bahasa sasaran dengan menggunakan padanan yang

${ }^{17}$ Koentjaraningrat, Pengantar Ilmu Antropologi ..., 153.

${ }^{18}$ Koentjaraningrat, Pengantar Ilmu Antropologi ..., h. 165.

${ }^{19}$ Alo Liliweri, Pengantar Studi Kebudayaan ..., h. 116.

${ }^{20}$ Tim, Kamus Besar Bahasa Indonesia (Jakarta: Balai Pustaka, 2007), h. 1183. 
terdekat dan wajar, pertama dalam hal makna dan kedua dalam hal gaya. ${ }^{21}$ Penerjemahan juga diartikan oleh Newmark sebagai pengalihan makna dari satu bahasa ke bahasa lain sebagaimana yang dimaksud oleh penulis teks. ${ }^{22}$

Bertolak dari pengertian di atas, penerjemahan dapat dijelaskan sebagai suatu cara pengalihbahasaan untuk mengungkapkan makna, pesan, atau amanat yang terkandung dalam bahasa sumber ke dalam bahasa sasaran dengan padanan kata yang memiliki makna serupa sesuai dengan maksud penulisnya agar dapat dipahami oleh pembaca. Ketepatan dalam menerjemahkan sebuah bahasa sumber ke dalam bahasa sasaran membuat pembaca dengan mudah memahami apa yang ingin disampaikan oleh penulis.

Penerjemahan bahasa sumber yang baik bergantung pada kemampuan komunikasi seorang penerjemah dalam memahami maksud dari penulis. Kemampuan penerjemah ini tidak hanya ditunjang oleh penguasaan terhadap bahasa sumber, akan tetapi juga harus memiliki kemampuan dalam memahami budaya dari bahasa sumber dan menjelaskan ke dalam bahasa sasaran. Machali berpendapat bahwa dalam proses komunikasi penerjemah melakukan komunikasi baru melalui hasil komunikasi yang sudah ada, yaitu dalam bentuk teks ${ }^{23}$ Oleh karena itu, penerjemah bertugas untuk memahami pesan yang ingin disampaikan oleh penulis dan menyampaikan pesan itu kembali kepada pembaca dalam bahasa sasaran.

Hasan dalam bukunya menegaskan bahwa proses penerjemahan dari satu bahasa ke bahasa lain bukanlah perkara yang mudah, terlebih lagi untuk penerjemah pemula. Penerjemah tidak hanya dituntut memiliki perbendaharaan kosakata yang banyak, akan tetapi juga dituntut memiliki pengetahuan tentang budaya dari bahasa yang akan diterjemahkan. Seorang penerjemah yang hanya mempunyai perbendaharaan kosakata tanpa diiringi dengan pemahaman tentang budaya dari bahasa yang diterjemahkan (khususnya budaya Arab) pada akhirnya hanya akan membingungkan pembaca. ${ }^{24}$

21Eugene A. Nida dan Charles R. Taber, The Theory Practice of Translation (Leiden: E.J. Brill, 1994), h. 12.

${ }^{22}$ Peter Newmark, A Textbook of Translation (New York: Prentice Hall, 1988), h. 5.

${ }^{23}$ Rochayah Machali, Pedoman bagi Penerjemah (Jakarta: Grasindo, 2000), h. 6.

${ }^{24}$ Hasan, Penerjemahan Arab-Indonesia (Banjarbaru: Atap Buku, 2017), h. 84. 
Hasan memberikan gambaran tentang penerjemahan ArabIndonesia yang berlandaskan kebudayaan dalam bahasa Arab di antaranya:

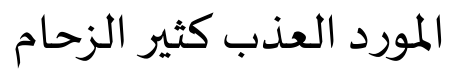

Secara harfiyah kata tersebut diterjemahkan dengan makna sumur air tawar itu dikerumuni banyak orang. Secara bahasa, terjemahan tersebut tidaklah salah, akan tetapi menyimpang dari maksud sebenarnya yang diinginkan bahasa sumber. Masyarakat Arab menggambarkan air tawar sebagai anugerah dan kenikmatan yang luar biasa karena kawasan Arab sangat sedikit curah hujan yang turun dibandingkan dengan Indonesia. Secara naluriah, manusia cenderung berkumpul dan berkerumun pada tempat dimana anugerah itu turun. Dalam peribahasa Indonesia, anugerah tersebut digambarkan sebagai sesuatu yang manis (gula) dan biasanya dikerubuti oleh semut. Maka terjemahan yang sesuai untuk peribahasa di atas adalah ada gula ada semut. Dari sinilah perlu ada pemahaman akan budaya dan adat istiadat dari bahasa yang akan diterjemahkan sebagai modal awal bagi seorang penerjemah disamping penguasaan kosakata dari bahasa yang akan diterjemahkan. ${ }^{25}$

\section{Hubungan Bahasa dan Budaya dalam Proses Penerjemahan Arab- Indonesia}

Bahasa memiliki aturan-aturan sosial yang harus diperhatikan ketika melakukan komunikasi dengan orang lain. Ketika suatu bahasa digunakan secara sembarangan maka akan memberikan implikasi yang berbeda terhadap lawan tutur. Sebagai contoh, seorang anak dari Amuntai yang kuliah di Banjarmasin, akan mengirim surat dengan bahasa Banjar yang halus kepada orang tuanya. Dia akan menggunakan ulun (daripada aku, unda, saya), sampiyan (daripada andika), dan dia tidak akan menggunakan bahasa Indonesia kecuali orang tuanya memang menggunakan bahasa sehari-hari bahasa Indonesia.

\footnotetext{
${ }^{25}$ Hasan, Penerjemahan ..., h. 85-86.
} 
Holmes mengemukakan bahwa faktor sosial yang berpengaruh terhadap wujud pemakaian bahasa adalah usia penutur. ${ }^{26}$ Penelitian dialek sosial telah memberikan banyak informasi tentang pola ucapan dan tata bahasa yang digunakan oleh kelompok umur yang berbedabeda. Konsep mengenai kompetensi komunikatif pertama kali diperkenalkan oleh Hymes di pertengahan tahun 1960. Hymes tertarik pada tingkat kompetensi yang diperlukan penutur agar mereka mendapat keanggotaan dari komunitas ujaran tertentu. Dia meneliti mengenai faktor-faktor apa saja, terutama faktor sosio-budaya yang diperlukan selain kompetensi gramatikal oleh penutur yang terlibat di dalam interaksi bermakna. Hymes menunjukkan bagaimana variasi bahasa berkorelasi dengan norma-norma sosial dan budaya dari interaksi publik tertentu, dari peristiwa ujaran (speech event).

Sebuah sebuah tindak komunikasi, penerjemahan yang baik tidak akan terjadi tanpa penguasaan bahasa sumber oleh penerjemah. Akan tetapi, penguasaan bahasa sumber tersebut harus pula ditunjang oleh pemahaman terhadap budaya tempat bahasa sumber itu berasal. Hal ini terjadi karena ketika seorang penerjemah mengalihbahasakan sebuah teks tertulis dari bahasa sumber kepada bahasa sasaran, maka penerjemah juga harus memiliki kemampuan untuk memahami unsur eksternal yang berpengaruh terhadap teks bahasa sumber yang diterjemahkan.

Proses pemahaman budaya yang melatarbelakangi sebuah bahasa sumber ini terjadi karena setiap teks tertulis selalu dipengaruhi oleh dua sisi, internal dan eksternal. Unsur internal berhubungan dengan unsur linguistik, sedangkan unsur eksternal berhubungan pengaruh nilai-nilai budaya, sosial politik, dan ekonomi pada bahasa sumber, selain itu biografi penulis sangat berperan penting dalam tulisan yang dihasilkan. Pengaruh unsur eksternal dalam teks tertulis ini terjadi karena sebuah tulisan tidak bisa dimaknai hanya melalui faktor linguistik semata, tetapi juga berdasarkan faktor-faktor pembentuk lainnya.

Dalam buku "Penerjemahan Arab-Indonesia Antara Bahasa dan Budaya" yang ditulis oleh H. Hasan, MA, Hum secara rinci menjelaskan bagaimana bahasa dan budaya saling berkelindan dan mempengaruhi satu dengan lainnya. Selain itu, juga dijabarkan bahwa dalam proses

${ }^{26}$ Janet Holmes, An Introduction to sociolinguistics. Second edition. (London: Longman, 2001), h. 186. 
menerjemahkan sebuah teks dari bahasa sumber ke bahasa sasaran juga menuntut kemampuan dari seorang penerjemah untuk memahami kondisi sosial budaya dari suatu masyarakat pemakai bahasa sumber tersebut. Pemahaman seorang penerjemah terhadap kebudayaan bahasa sumber ini berperan penting ketika penerjemah menemukan kata, istilah, ungkapan atau metafora bahasa yang khas dan hanya terdapat dalam bahasa sumber. Penerjemahan tidak hanya dilakukan kata per kata secara harfiah, tetapi seorang penerjemah yang baik harus memiliki kemampuan untuk mengalihbahasakan bahasa sumber ke dalam bahasa sasaran sesuai dengan kaidah dan makna yang terkandung dalam bahasa sasaran. Selain itu, dalam menerjemahkan sebuah teks, terkadang penerjemah harus pula mengetahui apa yang melatarbelakangi teks tersebut ada.

Menerjemahkan sebuah teks tertulis berbahasa Arab ke dalam Bahasa Indonesia tentu harus memahami bahasa Arab secara lisan maupun tertulis, selain itu juga harus memahami bahasa Indonesia secara baik dan benar. Pemahaman kedua bahasa ini penting untuk menghasilkan sebuah karya terjemah yang mudah dibaca dan pesan dari penulis buku itu sampai kepada pembaca dengan benar. Misalnya, untuk menerjemahkan sebuah teks yang berisi tentang keagamaan, maka seorang penerjemah harus menguasai konsep teologis tentang agama tersebut. Hoed mengatakan bahwa untuk menerjemahkan teks yang bersifat keagamaan, penerjemah wajib menguasai konsep teologisnya. ${ }^{27}$ Menurut dia, penguasaan konsep teologis akan memudahkan penerjemah dalam memahami pesan pada teks sumber dan mengalihbahasakan ke dalam ke teks sasaran.

Pada proses penerjemahan sebuah buku, seorang penerjemah harus membaca teks yang akan dia terjemahkan berulang-ulang agar penerjemah paham apa yang dimaksudkan oleh penulis. Penerjemah harus memiliki rujukan berupa kamus bahasa sumber dan bahasa sasaran, kamus istilah, dan ensiklopedi untuk menemukan makna leksikal sebanyak-banyaknya. Selain makna leksikal, makna sekunder, makna figuratif, dan fungsi retoris kata, frasa, klausa, atau kalimat harus pula dicatat dengan teliti. Seorang penerjemah yang baik harus memahami secara utuh dan menyeluruh teks tulisan sekaligus 34.

${ }^{27 B e n n y ~ H . ~ H o e d, ~ P e n e r j e m a h a n ~ d a n ~ K e b u d a y a a n ~(J a k a r t a: ~ P u s t a k a ~ J a y a, ~ 2006), ~}$ 
memahami pula sasaran atau pembaca dari teks tersebut untuk memperlancar proses penerjemahan yang dilakukan.

Sebagai sebuah karya ilmiah yang membahas tentang penerjemahan bahasa Arab ke dalam bahasa Indonesia, buku ini lebih banyak membahas tentang bahasa, budaya, dan penerjemahan secara umum. Untuk penerjemahan bahasa Arab ke bahasa Indonesia hanya masuk pada beberapa contoh yang yang dibuat penulis, misalnya tentang konteks metapora atau ungkapan yang ada dalam bahasa Arab dan menjelaskan bagaimana metafora itu disesuaikan dengan konteks bahasa Indonesia. Sebaiknya ada bab khusus yang membahas tentang penerjemahan bahasa Arab ke bahasa Indonesia secara metode, prosedur, dan teknik penerjemahan yang tepat dan sesuai dengan bahasa sumber dan bahasa sasaran. Akan tetapi secara keseluruhan akan kita temukan khazanah keilmuan yang sangat luar biasa dari buku tersebut, sehingga bisa menjadi rujukan ilmiah bagi siapa saja yang ingin mengkaji tema tentang bahasa dan budaya.

\section{Penutup}

Bahasa berperan sangat penting dalam kehidupan bermasyarakat. Tanpa bahasa, masyarakat tak mungkin bisa berinteraksi, dan sebaliknya tanpa masyarakat, bahasa tak akan pernah ada. Bahasa tidak hanya berfungsi sebagai alat komunikasi, tetapi lebih dari itu bahasa juga berfungsi sebagai penyebar ilmu pengetahuan, seni, dan teknologi. Bahasa memiliki aturan-aturan yang harus disepakati antarpemakai bahasa, dan apabila aturan itu sengaja dilanggar maka sering terjadi kesalahan komunikasi, penafsiran terhadap isi percakapan, bahkan kesalahpahaman.

Dalam proses penerjemahan, penguasaan bahasa sumber saja tidak mencukupi, seorang penerjemah juga harus mengetahui latar belakang sosial budaya, tujuan, dan sasaran pembaca dari teks tulisan tersebut. Kemampuan ini harus dimiliki oleh seorang penerjemah karena menerjemahkan sebuah teks juga menerjemahkan sebuah budaya suatu masyarakat pengguna bahasa sumber kepada masyarakat pengguna bahasa sasaran. Selain itu, penguasaan unsur internal dan eksternal terhadap teks sumber akan memudahkan seorang penerjemah untuk mengalihbahasakan ke dalam teks sasaran. 


\section{DAFTAR PUSTAKA}

Alwasilah, A. Chaedar, Sosiologi Bahasa. Bandung: Angkasa, 1986.

Chaer, A dan Leoni A, Sosiolinguistik: Perkenalan Awal. Jakarta: Rineka Cipta, 2004.

Douglas, M, Traditional Culture-Let's Hear No More About It dalam Culture and Public Action Edited byVijayendra Raoand Michael Walton. Stanford, California: Stanford University Press, 2004.

Fishman, Joshua A, The Sosiology of Language. Massachussetts: Newbury House, 1976.

Hakim, Aunul, "Bahasa dan Budaya" Turats Vol 6, no. 1 (2014).

Hasan, Hasan. Penerjemahan Arab-Indonesia Antara Bahasa dan Budaya. Banjarbaru: Atap Buku, 2017.

Hatmiati, Pemali dalam Tradisi Lisan Masyarakat Banjar (disertasi tidak diterbitkan). Malang: PPS Universitas Negeri Malang, 2016.

Hoed. Benny H, Penerjemahan dan Kebudayaan. Jakarta: Pustaka Jaya, 2006.

Holmes, Janet, An Introduction to sociolinguistics. Second edition. London: Longman, 2001.

Husin, "Perkembangan dan Perubahan Kurikulum Pendidikan Islam di Indonesia", Addabana 1, no. 2 (2018).

Ibrahim, Abdul Syukur, Kajian Tindak Tutur. Surabaya: Usaha Nasional, 1993.

Jenks, C, Culture Studi Kebudayaan. Yogyakarta: Pustaka Pelajar, 2013.

Kaimuddin, "Pengembangan Kurikulum Pendidikan Tinggi", Jurnal AlTa'dib Vol. 8, no. 1 (2015).

Koentjaraningrat, Pengantar Ilmu Antropologi. Jakarta: Rineka Cipta, 2009.

Larson, Mildred L, Penerjemahan Berdasarkan Makna: Pedoman untuk Pemadanan Antarbahasa (diterjemahkan oleh Kencanawati Taniran dari Meaning Based Translation, A Guide to Crosslanguage Equivalence). Jakarta: Penerbit ARCAN, 1989.

Liliweri, Alo, Pengantar Studi Kebudayaan. Bandung: Nusa Media, 2014.

Machali, R, Pedoman bagi Penerjemah. Jakarta: Grasindo, 2000. 
Newmark, P, A Textbook of Translation. New York: Prentice Hall, 1988.

Nida, Eugene, A dan Charles R. Taber, The Theory Practice of Translation. Leiden: E.J. Brill Publisher, 1994.

Rauf, Abdullah Zainur, "Dialektika Bahasa Dan Budaya," Al-Qudwah, (2006).

Spradley, J.P and McCurdy, D.W, Conformity and Conflict Reading in Cultural Anthropology. United States of Amerika: Pearson Education, Inc., 2012.

Tim, Kamus Besar Bahasa Indonesia. Jakarta: Balai Pustaka, 2007.

Zamzani, "Eksistensi Bahasa Indonesia Dalam Pendidikan Berbasis Keragaman Budaya", Dialektika 1, no. 2 (2014). 
Hatmiati dan Husin: Budaya Dalam Penerjemahan Bahasa 